\title{
TiO2 nanoparticles induced micronucleus formation in human liver (HepG2) cells: comparison of conventional and flow cytometry based methods
}

\author{
NV Srikanth Vallabani", Ritesh K Shukla, Dinesh Konka, Ashutosh Kumar, Sanjay Singh, Alok Dhawan \\ From International Conference on Human Genetics and 39th Annual Meeting of the Indian Society of \\ Human Genetics (ISHG) \\ Ahmadabad, India. 23-25 January 2013
}

\section{Background}

$\mathrm{TiO}_{2}$ nanoparticles $\left(\mathrm{TiO}_{2} \mathrm{NPs}\right)$ are extensively used metal oxide NPs in cosmetics, as an additive in pharmaceuticals, food colorant etc. Being widely used NPs, their toxicity assessment studies help in understanding the adverse effects to the humans. It is likely that NPs exposure to the humans can be through different routes but will finally reach the liver. Therefore, an attempt was made to explore the genotoxicity of $\mathrm{TiO}_{2} \mathrm{NPs}$ on human liver cells (HepG2).

\section{Materials and methods}

$\mathrm{TiO}_{2}$ NPs were characterized by transmission electron microscopy (TEM) for their primary size, shape and dynamic light scattering for their size, size distribution and zeta potential in culture medium. Cellular uptake of $\mathrm{TiO}_{2}$ NPs in HepG2 cells was detected using flow cytometry method. Moreover, ultrathin sections of cells were analysed using TEM to visualise the internalisation of $\mathrm{TiO}_{2}$ NPs. The genotoxic potential of $\mathrm{TiO}_{2} \mathrm{NPs}$ was assessed by micronucleus assay using the conventional and flow cytometry methods.

\section{Results}

TEM analysis of $\mathrm{TiO}_{2}$ NPs revealed a mean diameter size of 30-70 $\mathrm{nm}$ and DLS measurements showed a mean hydrodynamic diameter and zeta potential of $192.5 \pm 10 \mathrm{~nm}$ and $-11.4 \pm 1.2 \mathrm{mV}$, respectively. The electron microscopy and flow cytometry studies for particle internalisation showed a significant cellular uptake of $\mathrm{TiO}_{2} \mathrm{NPs}$ in the human liver cells (HepG2). A significant $(\mathrm{p}<0.05)$ induction in micronucleus formation was observed at $20 \mu \mathrm{g} / \mathrm{ml}$ of $\mathrm{TiO}_{2}$ NPs exposure when compared to control cells. However further treatment to HepG2 with higher concentrations (40 and $80 \mu \mathrm{g} /$ $\mathrm{ml}$ ) showed a decrease in micronucleus formation than $20 \mu \mathrm{g} / \mathrm{ml}$.

In contrary, the flow cytometric results exhibited a significant concentration dependent induction of micronucleus in HepG2 cells exposed to all concentrations (20, 40 and $80 \mu \mathrm{g} / \mathrm{ml}$ ) of $\mathrm{TiO}_{2}$ NPs than control.

\section{Conclusion}

The difference in the micronucleus frequency obtained from conventional and flow cytometry methods in HepG2 may be due to the accumulation of $\mathrm{TiO}_{2} \mathrm{NPs}$ on prepared slides, which hinders the counting of micronucleus (in conventional method). However, in the flow cytometry analysis, these nanoparticles do not interfere with the optics. Hence, it is proposed that in the case of NPs treatment, flow cytometry based micronucleus assay should be used instead of the conventional method.

\footnotetext{
Acknowledgements

The financial assistance for the Centre for Nanotechnology Research and Applications (CENTRA) by The Gujarat Institute for Chemical Technology (Grant no. ILS/GICT/2013/003) is acknowledged.
} 
- Convenient online submission

- Thorough peer review

- No space constraints or color figure charges

- Immediate publication on acceptance

- Inclusion in PubMed, CAS, Scopus and Google Scholar

- Research which is freely available for redistribution 